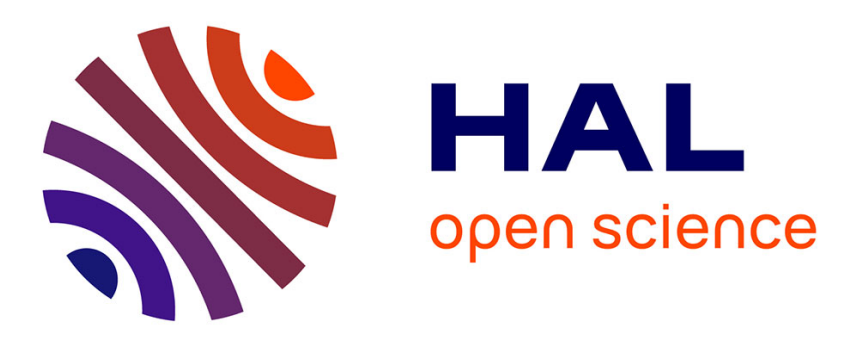

\title{
Small firms in the sustainable transformation of food industry: entangling entrepreneurship and activism in grassroots innovation processes
}

Emilie Lanciano, Séverine Saleilles

\section{- To cite this version:}

Emilie Lanciano, Séverine Saleilles. Small firms in the sustainable transformation of food industry: entangling entrepreneurship and activism in grassroots innovation processes. Sociologia del Lavoro, 2017, 147, pp.111 - 127. 10.3280/sl2017-147006 . halshs-01879116

\section{HAL Id: halshs-01879116 \\ https://shs.hal.science/halshs-01879116}

Submitted on 22 Sep 2018

HAL is a multi-disciplinary open access archive for the deposit and dissemination of scientific research documents, whether they are published or not. The documents may come from teaching and research institutions in France or abroad, or from public or private research centers.
L'archive ouverte pluridisciplinaire $\mathbf{H A L}$, est destinée au dépôt et à la diffusion de documents scientifiques de niveau recherche, publiés ou non, émanant des établissements d'enseignement et de recherche français ou étrangers, des laboratoires publics ou privés. 
Manuscrit auteur de l'article: Lanciano E., Saleilles S. (2017), Small firms in the sustainable transformation of food industry: Entangling entrepreneurship and activism in grassroots innovation processes, Sociologia del Lavoro, n. 147, pp. 111-127, DOI:10.3280/SL2017-147006

\section{Small firms in the sustainable transformation of food industry: Entangling entrepreneurship and activism in grassroots innovation processes}

\section{$\underline{\text { Abstract in Italian }}$}

La letteratura accademica dello studio dei movimenti sociali e delle piccole e medie imprese, pone l'accento sulla relazione che può intercorrere tra l'azione di alcuni movimenti sociali e l'azione imprenditoriale ed economica: attivisti ed imprenditori sociali non sono attori distinti con logiche separate ma usano tattiche e piani d'azione simili.

Questo articolo si interessa alla combinazione dell'attivismo civico e politico e l'imprenditorialità e vuole dimostrare come tali interazioni possano esistere e funzionare in modo innovativo in piccole imprese al fine di contribuire alla trasformazione di un settore nell'ottica di uno sviluppo sostenibile.

Viene studiato in particolar modo il settore dell'industria alimentare e dei cosiddetti sistemi alimentari alternativi. In un contesto di crescente interesse e sensibilità verso modelli alimentari più sostenibili, come riescono le piccole imprese a combinare l'attivismo e l'imprenditorialità per inquadrare i processi di grassroots innovazione e tradurre questo quadro in modello organizzativo?

\section{$\underline{\text { Abstract in English }}$}

The literature in Social Movement Theory, Organization Studies and Entrepreneurship emphasizes on the linkages between social movement action and economic organization. Indeed, social entrepreneurship and social movement studies tend to be more and more linked: activists and social entrepreneurs do not represent separate and distinct actors with different logics of action, but tend to transfer their tactics, such as framing, mobilization, protest and negation.

This paper explores how activism and entrepreneurship can be combined in an innovative way by small firms in order to contribute to an industry's transformation towards sustainable development.

We specially investigate the field of food industry and Alternative Food Networks. In a context of growing interest and sensitivity towards more sustainable food models, how do small firms combine activism and entrepreneurship to frame grassroots innovation processes and translate this frame into organizational model?

Keywords in Italian:_grassroots innovazione, PMI, cooperazione, industria alimentare

Keywords in English: grassroots innovation, SME, food industry, cooperation 


\section{Introduction}

The sustainable transformation of an industry is a complex and collective process, which implies networks of state, civil society, market-based actors and institutions (Smith et al., 2005). As a process of discovering opportunities in market failures that detract from sustainability (Dean and McMullen, 2007), or as a process of transforming institutions by altering or creating norms, property rights and government legislation (Schaltegger, 2002; Pacheco et al., 2010), entrepreneurship can help create a sustainable future (Gibbs, 2009).

The literature in Social Movement Theory, Organization Studies and Entrepreneurship emphasizes on the linkages between social movement action and economic organization. Indeed, social movement and social entrepreneurship studies tend to be more and more linked (Van den Broek et al., 2012): activists and social entrepreneurs do not represent separate and distinct actors with different logics of action (Vasi, 2009), but tend to transfer their tactics, such as framing, mobilization, protest and negation (Mair and Marti, 2006). If linking of social entrepreneurs with social movements makes sense at a regime level, the combination of their practices is still not evident at the organizational level.

This paper explores how activism and entrepreneurship can be combined in an innovative way by small firms in order to contribute to an industry's transformation towards sustainable development. The industry that is being investigated is the food industry where a wide literature is available to describe how social activists struggle with the market to create new rules of consumption and production (Dubuisson-Quellier et al., 2011). However, the role of small business, acting in this field, is less developed. Indeed, the development of AFN - Alternative Food Networks (Goodman et al., 2012), even based on the participation and the cooperation with consumers, is deeply based on firms that activate new exchange and organizational mechanisms for providing food products. In a context of growing interest and sensitivity towards more sustainable food models, how do these small firms combine activism and entrepreneurship to frame grassroots innovation processes and translate this frame into organizational model?

The paper is organized as follows. In the next section, we present previous research that focused on the combination of activism and entrepreneurship in small firms. Then, we explain the research method used, based on a case study conducted within a French cluster of small firms operating in organic, local food and/or short food supply chains. Finally, we present and discuss the case study findings, which allow us to highlight the challenges and the ways of combining the best of these two worlds.

\section{Entangling entrepreneurship and activism in grassroots innovation processes: a conceptual framework}

We propose to combine the literature on AFN, grassroots innovation processes, social entrepreneurship, social movement and institutional work to explore innovation practices and processes through which small firms can combine activism and entrepreneurship to change the food industry.

\subsection{Alternative Food Networks as grassroots innovation processes}

The sustainable food supply chain is a mosaic-like field of Alternative Food Networks (AFN). There are many different expressions of the search for sustainable practices, from WEAK experiences, enacting partial change, to STRONG experiences, committed to radically change practices (Watts et al., 2005). "Strong AFNs" seem better suited to create social and political change because they challenge the foundations of the conventional food system (Follett, 2009). Increasingly, they represent spaces where producers and consumers go beyond the practices and relationships related to food provisioning and become engaged together in new, more significant forms of food citizenship (Renting et al., 2012).

These spaces of interaction and development of new food practices can be seen as expression of a broader movement aimed at reshaping and repositioning economy within society, that of Solidarity Economy (Laville, 2009). Strong Alternative Food Networks (SAFN) prioritize social usefulness, 
democratic governance, fair trade and support of peasant and organic agriculture of economic projects. They are both political and economic in nature: they want to criticize the actual food provision chain and act to develop another. Although not relevant in size, these firms built around new approaches to food matters contribute to democratize the mainstream agro-food system, both culturally and practically. At its basis, there are significant processes of growth of knowledge and empowerment involving producers and consumers.

SAFN are seen as market agencements, sociotechnical arrangements capable of market action (Le Velly R. \& Dufeu I., 2016). They are not passive intermediaries between pre-existing supply and demand. They participate in educating and equipping consumers, but they also act on supply by establishing a reference frame of practices that growing numbers of people are assumed to expect. Markets' effects must be seen as the results of their various arrangements.

As they contribute to create new borders between civic and economic action, to change market rules and finally to advocate alternative pathways of innovation, SAFN contribute to produce grassroots innovation (Horwitch and Mulloth, 2010 ; Smith et al., 2014 ; Fressoli et al., 2014). Grassroots innovation are innovation coming from the 'grassroots', meaning that it is generally a result of a bottom-up process emanating from communities and users. Based on prior work on social movement framings of grassroots innovation, Fressoli et al. (2014) propose to consider frames and models of inclusive innovation as two different - and recursively connected - aspects of the process of building alternative pathways of innovation.

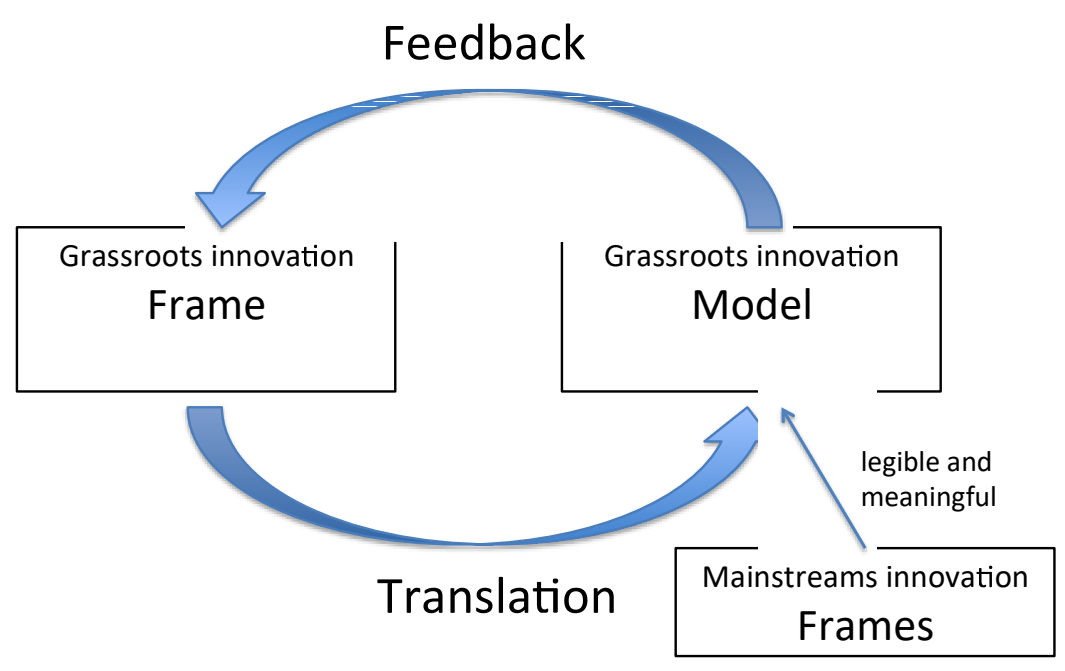

Figure 1 - From frame to model in grassroots innovations processes

The frame allows to bring the actors together. It is a particular way of problematizing the world, constructed ad hoc to facilitate the emergence of collective action. But frame do not necessarily constitute a blueprint for mobilization and socio-technical experimentation. The frame needs to be translated into model, and this model in turn has to be legible and meaningful to framings associated with mainstream institutions. The implementation of a model can also test ideas drawn from different frames and allow processes of learning that would eventually create feedback and transform the framings as well. Fressoli et al. (2014) argue that it is important to look at models as devices for opening spaces and processes of experimentation, empowerment and alternative ways of knowledge production.

While studying grassroots innovations in the sustainable food sector, Rossi (2017) explores their internal dynamics and how they manage their growth and the diffusion of their innovation out of the niche. She shows that the translation of the frame into alternative practices is a complex process, 
which requires proper changes in multiple domains, and the active engagement of all stakeholders. In a perspective of growth, this translation of the frame into model has to face organizational efficiency requirements and greater complexity. Notably, an iterative collective learning process is crucial to align attitudes and behaviour between new and old network members.

Previous research in social entrepreneurship and social movement highlight the combination of activism and entrepreneurship in sustainability-driven small firms.

\subsection{Entangling entrepreneurship and activism in practice}

In the literature, social entrepreneurship and social movement studies tend to be more and more linked (Mair and Marti, 2006, Spear, 2010, Van den Broek et al., 2012, Vasi, 2009).

Social enterprises share the pursuit of revenue generation with organizations in the private sector as well as the achievement of social (and environmental) goals of non-profit organizations (Di Domenico et al., 2010). Lots of conventional entrepreneurship practices (like new value creation via a process of bricolage, the creative destruction of organisational models, and catalytic exogenous change) can be applied equally well to social entrepreneurship (Nicholls, 2010). But social entrepreneurship is a mosaic-like field from market-driven (who are in a win-win logic and do not necessarily strive for radical social change) to sustainability-driven. Sustainability-driven entrepreneurs have principles of organisation design, which diverge in important ways from the conventional principles of entrepreneurship. Parrish (2010) has highlighted five design principles of a 'perpetual reasoning'. It includes resource perpetuation (i.e. produce benefit streams), benefit stacking (i.e. stack as many benefits as possible onto each operational activity), strategic satisficing (i.e. strategically identify satisfactory outcomes of multiples objectives), qualitative management (i.e. use expected quality of outcomes and processes as decision criteria) and worthy contribution (i.e. structure benefit streams to privilege worthy recipients).

While most small firms operate under conditions of resource scarcity (Torres and Julien, 2005), sustainability-driven small firms face a specific set of challenges because they purposely locate their activities in areas where markets function poorly. To face these challenges, they use social bricolage (Di Domenico et al., 2010), which is a process that involves making do, the refusal to be constrained by limitations and improvisation (like conventional entrepreneurship bricolage) but also social value creation, stakeholder participation and persuasion (which seems to be specific to social entrepreneurship). As they need to establish support and to access resources from market-based institutions, sustainability-driven small firms may be more susceptible to isomorphic pressures. Indeed, they are exposed to the same risk of institutionalization than social movements (Spear, 2010). Tactics used by social movements, such as framing, mobilization, protest and negation can be useful for social entrepreneurs (Mair and Marti, 2006). So, social movement theory is relevant to the study of sustainability-driven small firms.

Issued from a dynamic social process, which includes conflictual forces (Tourraine, 1985), social movements are alternative spaces for developing new meanings and new systems of praxis, which can be continually reproduced. To achieve their desired social change, activists - members of social movements - often draw on entrepreneurial strategies that help them to mobilize and exploit resources - such as donations, media attention and moral support - in a more efficient and creative way (Van den Broeck et al., 2012). Activists and social entrepreneurs do not represent separate and distinctly actors with different logic of action (Vasi, 2009).

Van den Brock et al. (2012) propose a new framework, which positions transformational social entrepreneurs (term used by Nicholls, 2010) as a specific type of social entrepreneurship that combines (radical) social change and the fulfillment of social needs. This type is similar to the social engineer of Zahra et al. 2010) or the sustainability-driven entrepreneur of Parrish (2010). 


\begin{tabular}{|c|c|c|c|}
\hline & \multicolumn{2}{|c|}{ Fulfilling social needs } \\
\hline & & High & Low \\
\hline 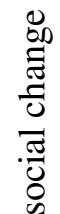 & High & $\begin{array}{l}\text { Transformational } \\
\text { social entrepreneurs } \\
\text { (Zahra et al, 2009; } \\
\text { Nicholls, 2010) }\end{array}$ & Activists \\
\hline $\begin{array}{l}\text { ज्ञ } \\
\stackrel{0}{0}\end{array}$ & Low & Social entrepreneurs & Entrepreneurs \\
\hline
\end{tabular}

Table 1- Transformational social entrepreneurs, desire for social change and fulfill social needs (Van den Broeck et al. 2012)

Transformational social entrepreneurs - entrepreneurs who combine activism and entrepreneurship introduce rules and organize their dissemination through institutional work (Lawrence and Suddaby, 2006). These authors divide the process of institutional creation into three categories. The first includes advocacy, defining, vesting, and reflecting the "political work in which actors reconstruct rules, property rights and boundaries that define access to material resources" (Lawrence and Suddaby, 2006: 15). The second set of practices, constructing identities, changing norms and constructing networks, emphasize actions in which actors' belief systems are reconfigured. The final category includes activities that involve associating new practices with the old, theorizing and elaborating chains of cause and effect, and educating, i.e. providing actors with the necessary skills and knowledge to support the new institution.

\section{Small firms in the sustainable transformation of food industry: the GRAP case}

\subsection{Method and presentation of the case}

We collected data on a cluster of small firms operating in organic, local food and/or short food supply chains in the Lyon area in France. The city of Lyon is known for its gastronomy culture based on the proximity of the periurban rural areas that bring a diversity of fresh products. However, this gastronomic tradition has long been concerned mainly with high-income people or tourists who could afford a great reputed restaurant. That is why, since 10 years, new initiatives emerge that aim to reactive a diffused culture of food, based on the quality of the products, reasonable prices and strong relationships between producers and consumers.

The empirical research adopted is a mix qualitative methodology. First, we proceeded with 8 semistructured interviews of the two founders, employees and members of the GRAP organization. Second, we adopt an ethnographic research; we became actors of the process we study (Greenwood, et al., 1993) through our direct participation in some activities of GRAP, notably the construction of an organizational cluster, which the objective was to manage the cooperation between sustainable food sector firms of the solidarity economy. All the observations have been done between 2013 and 2016; the founders have been interviewed several times, once a year in order to understand the transformation and the strategy of the organization. Finally, our methods were constructivist in the sense that we considered both the manifestation of action but also the reflexivity of actors in the way they design their own action.

GRAP (Groupement Régional Alimentaire de Proximité) was founded in Lyon in January 2013 and has the status of a SCIC (Société Coopérative d'Intérêt Collectif) ${ }^{1}$ under the French law. GRAP

\footnotetext{
${ }^{1}$ A SCIC (Société Coopérative d'Intérêt Collectif) is a Co-operative Company of Collective Interest. SCIC are collective interest cooperatives bringing together employees, users, volunteers, and local authorities to implement local development projects.
} 
currently hosts 21 businesses (64 workers) operating in organic, locally produced food and/or short food supply chains (grocers, import business, restaurant, supermarket, restaurant) for a provisional turnover of 5 millions $€$. Issues addressed by the project are the change of scale of short food supply chains, professionalization of the actors in the sector, improvement of working conditions, minimizing entrepreneurial risks.

GRAP is a cooperative framework for undertaking projects where entrepreneurs can emerge from isolation and cooperate with other entrepreneurs, exchange products, services and support. It offers several services to small firms, including legal hosting, stock management, accounting, financial engineering, training, entrepreneurship support and business development, etc. It also aims to create synergies between the different firms (by pooling orders, transport and storage facilities, etc.) and promotes cooperative governance and innovative way of doing business and working in the food sector.

The small firms are selected for their ethical approach, the ecological and social impact of their activity, the economic viability of their project and the potential for cooperation and synergies with the other small firms already present in GRAP. The majority became part of GRAP during the start-up of the business, with the exception of 3 petits pois and Prairial.

\begin{tabular}{|l|l|}
\hline \multicolumn{1}{|c|}{ Name } & \multicolumn{1}{c|}{ Activity } \\
\hline 3 petits pois & Grocery \\
\hline Petits zestes & Short supply chain (Mediterranean products) \\
\hline La fabrique des producteurs & Restaurant \\
\hline La Fourmillière & Bakery \\
\hline Elodie D. chocolatière & Chocolate maker \\
\hline La Super Halle & Grocery + farm shop + restaurant \\
\hline Des Vins et des Hommes & Short supply chain (Wine) \\
\hline Coolivri & Delivery service \\
\hline Coeur d'Artichaut & Grocery \\
\hline Prairial & Grocery \\
\hline Croc Bauge & Grocery \\
\hline L'épicerie du coin & Grocery \\
\hline Le Grain dans le Grenier & Grocery \\
\hline Les bon plans de Tonton & Short supply chain \\
\hline Mélim'élo & Food craft \\
\hline Le pain de Garance & Bakery \\
\hline Chocolalala & Chocolate maker \\
\hline Philosophie végétale & Caterer \\
\hline Gout'chou & Caterer \\
\hline Mamie Marie & Grocery \\
\hline Vrac en Vert & Grocery \\
\hline
\end{tabular}

Table 2 - Presentation of the small firms which are part of GRAP in 2017

The study of GRAP allowed us to explore how activism and entrepreneurship issues are combined in the framing of the organization. In this case, two levels were identified in the translation process of this frame into a model (2.2). First an innovative organizational model is constructed to resolve the growth/singularity dilemma. Second, work participation and work balance as a considered as crucial issues to permit grassroots innovations. A discussion also examines the underlying challenges facing 
GRAP, in order to further document the implications of these results.

\subsection{Translation of frame into an innovative model}

The translation from frame to model was mainly done in two directions. First, the challenge was to build an organizational model that enables the cooperation between small firms and mutualize resources to get broader market spaces. Second, the translation process was targeted to work participation and work balance issues.

\section{An innovative organizational model to solve the growth/singularity dilemma}

The first challenge was to develop an innovative organizational model based on cooperation and pooled resources in order to facilitate the development of small firms implicated and the creation of new firms. In other words, in order to defend their niche and diffuse it, these small firms have to invent entrepreneurial forms based on stable and innovative business models. Their stated objective was as follows: "to devise, study, experiment with and promote new forms of cooperation and economic innovation in the social, solidarity and environmental economy" (General Meeting). Moreover, the project is resolutely offensive and aims to take "market shares to the big suppliers and distributors, not to people who develop the same type of project." (Founder 2)

This meant therefore inventing technical solutions and new tools with which to consolidate and develop sustainability-driven small firms, as well as demonstrating the innovative nature of these solutions.

The definition of the organizational and business form of GRAP has been the crucial point of this innovation process. Indeed, in order to facilitate its legitimacy and diffusion, it was necessary to demonstrate that the proposal was both original and innovative. One of the founders explains their intention: "Our first idea was to facilitate the emergence of new projects and precisely to organize the interactions and synergies between projects. That is why we have been inspired both by the Mondragone experience in Spain and by the industrial districts in Italy. Actually, our first name was " the district of solidarity ». Then, we saw that entrepreneurs work better together when they belong to the same organization: we looked for a kind of organization that protects people and projects through a formal entity but also that guarantees autonomy for them." (Founder 1)

The both experiences of Mondragone Cooperative ${ }^{2}$ in Spain and industrial district are mobilized as a general frame. It helps to design a direction to their project and to give a proof that such project can be realized. However, this two general experiences do not refer to the same objective: the Mondragone experience is directly linked to an alternative and cooperative experience while industrial district refers more to a territorial productive organization for SME. The third reference of Coopératives d'Activités et d'Emplois (CAE) is more relevant in the sense that it brings the operational form of the project GRAP. A CAE is a Business and Employment Cooperative (BEC) that serves as the legal entity and surrogate for emerging projects. It thereby allows the entrepreneurs involved to benefit from employee status, pooled support services (accounting, support, etc.) and any potential operational synergies with other entrepreneurs. Collective projects may emerge from the proximity of entrepreneurs. Born in Lyon in 1995, the CAE have gradually evolved into "shared enterprises": establishment of a worker's representation, formation of important indivisible reserves and taking of collective risks (Veyer and Sangiogio, 2006). However the collective and cooperation action is only based, in the case of CAE, on the share of risks and the cooperative principles. It means that single entrepreneurial activities are not linked ex ante and the complementarities among activities are not fully exploited. The CAE reference brings to the founders of GRAP the boundary and the form of the cooperation model, but they translate it into a single-sector perspective and precisely in the food sector, in order to generate external effects of cooperation but also collective strategies.

The organizational model created by GRAP has the same advantage in solving the growth/singularity

\footnotetext{
${ }^{2}$ The Mondragon Corporation is a corporation and federation of worker cooperatives based in the Basque region of Spain. It was founded in the town of Mondragon in 1956 by graduates of a local technical college
} 
dilemma than the hypogroup (Marchesnay, 1991) which is an organizational configuration adapted to sustain small businesses development. It permits to articulate the professionalization of management and more formalized modes of control on tone hand, and the conservation of features specific to the small size of his company on the other hand (Debray, 20002). But GRAP's model is also innovative because small firms involved in it have the objective to support and secure the creation of new businesses in order to extend their niche and to promote the sustainable transformation of the food sector. To do this, they constitute indivisible reserves and allocate times, skills and employees to the support of others entrepreneurs.

\section{Work participation and work balance as a crucial issue}

Innovation practices are also related to work issues. Indeed the attention of founders has been focused on the conditions in which activities would be done.

Work participation is defined by Neumann (1989) as the structures and processes for organizing individual autonomy in the context of group responsibility and linked to system-wide influence. It can take a number of diverse forms as formal or informal, direct or not... It treats about the degree of involvement in decision and more broadly to the capacity of people to get a voice to the way the firm is organized and worked (Glew D.J, 1995). Here, the previous activist experience of founders and employees is crucial since the question of participation appears as a recurrent question. Precisely, a lot of them explain that the GRAP experience was a way "to go on with activism but to achieve more concrete objectives" (employee 1). They already get the tools and ideas of collective participation in decision-making and it deals with translating it into a business context. The objectives was so to create a non-vertical and mobile organization where people are involved in decision-making whatever its job position and where job position can change and evolve, according individual preference and work balance.

First, the organization creates spaces of collective decision where the whole diversity of stakeholders and employees are involved. The statute of employment and business cooperative brings the formal rules for the decision-making. The work governance is organized according the position of people in the organization: job employees, associated and integrated entrepreneurs and others shareholders are part of the board where the main decision and the strategy is designed once a year. Moreover, GRAP creates workgroups with specific purpose, as the integration of new incumbents. The composition of such workgroups is not only based on the skill criteria but also on the diversity of people represented.

Second, the capacity of people to get a voice is regulated to guarantee the real participation of people and to prevent the conscious and unconscious effects of domination. The members of the organization have therefore created a kind of toolbox, coming from the field of popular education and the new fields of conceptualization of direct democracy (sociocracy) Most of these arrangements concern group facilitation, designation of specific responsibilities and decision-making. Meetings are animated using techniques of brainstorming, positioning on cursors, Forum Theater, etc. Some devices require participants to ask themselves crucial questions to break down inhibitions and taboos: the dishonest questioning system consists in asking the participants taboo questions directly related to an issue of the organization and pushing them to develop arguments. The principle of election without a candidate is used systematically to assign a function, a role or authority to a person, without it being a candidate.

Another area of innovation practices related to the work issue concerns the balance between private and professional life. All the actors involved in GRAP are very careful to the negative effects of work activities and employment, such tiredness, exhaustion but also boredom. The imperative was therefore to foresee changes in the allocation of functions, in order to make commitments visible and to guarantee the rotation of experiments. The principle of job rotation is enforced and since the beginning of the organization, people move from a position to other. Moreover, sabbatical leaves are planned, especially for those most involved: it is a matter of relieving these people but also encouraging the rotation of responsibilities and pushing the structure to empower each small business owner. Further deliberation is encouraged with the possibility of new members being admitted to the board or to be spokesperson. 
Finally GRAP has to make visible issues and problems and to tackle individual difficulties and interindividual conflicts that the work may generate. The case of the functions of mediator and guardian angel illustrates well this idea. Indeed, like any organization, inter-individual tensions may occur within the organization. It was then decided to take charge of these tensions with the creation of a function of mediator. The mediator has a vocation to intervene before and during the friction, in order to defuse it. The function of mediator in fact proved quite ineffective, because it intervenes too late in the relationship. After reflections and discussions, the function of mediation has been reformulated in principle of "the guardian angel". Indeed, the idea is that individuals, all involved in stressful situations (creation of activity, economic uncertainty, etc.), need to be listened to. It is then a question of dedicating to each, a person available to listen to the concerns. This solution has the advantage of intervening before of a potential crisis and of introducing a reciprocal relationship since all the members of the organization are concerned.

\section{Discussion and conclusion}

Our case study highlights the challenges and the ways of combining the best of activism and entrepreneurship to allow sustainability-driven small firms to contribute to an industry's transformation towards sustainable development, despite their limited resources. We specially focused our analysis on a single case study in the Lyon area and we considered how actors translate their objectives (to set up an alternative food networks able to compete with the conventional firms) into practices and strategy. Two levels were identified. First, an innovative organizational model is constructed to resolve the growth/singularity dilemma. Second, work participation and work balance are considered as crucial issues to permit grassroots innovations.

First, the GRAP's innovative organizational model facilitates the development of small firms (pooling of services and resources) but also the growth of the niche (creation of new sustainability-driven small firms, political activities to overcome market barrier). It directly contributes to the structuration of an organizational field in the Lyon area and allows the emergence of a broader alternative food system that implies the participation of public authorities and civil society.

According to Hockerts and Wüstenhagen (2010), a true industry transformation towards sustainable development can be achieved only when some sustainability-driven small firms become more business-like and seek to grow proactively. But growth creates a paradoxical tension (Smith et al., 2013; Weinberg, 1998) for sustainability-driven small firms: although it allows a firm to improve its social and environmental impacts, sustainability values might be only partially maintained (Parrish, 2010) when growing, and growth might in turn threaten these expected impacts (Smith et al., 2013).

Thus, the case of GRAP enables to consider the plurality of forms of AFN. The GRAP case is particularly relevant because it is an integrated organization that implies the main actors of the food sector (producers, entrepreneurs, employees, intermediary actors and even public authorities) but excluding consumers. The project is precisely to ensure firms and to create new opportunities niches for firms. In others words, while others alternative food networks are based on the active participation of consumers (Brunori et al., 2012), the case of GRAP highlights another path of development of AFN.

Second, the case of GRAP underlines the fabric of innovation. Innovation is viewed as the art of attracting a growing number of allies who are making you stronger and stronger (Alkrich et al., 1988). At the same time as their innovation was being conceptualized, this information had to be disseminated. GRAP's actors undertook actions designed to promote the new model and build strategic alliances with other actors in order to overcome market barrier and to gain political access and influence (Pinkse and Groot, 2013). Their objective therefore was "to secure recognition for their initiative as a genuine social innovation that can be supported in the same way as technological innovation". Their strategic intentions clearly extended beyond the context of food alone, and their ambition was to secure legitimacy within the social and solidarity economy and entrepreneurship.

To achieve this, GRAP sought the involvement of researchers and intervened in training sessions that addressed the theme of the SSE. Academic output and research articles are perceived as tools of dissemination and persuasion that are just as effective as, for example, press committees in developing 
the legitimacy of an enterprise. It is also felt that cooperation with researchers reinforces the conceptualization process, as researchers are supposed to provide more objective analysis of their practices and strategies.

Third, the paper has shown that all the actors involved in GRAP are very careful to the negative effects of power on decision-making and of stressful work on life. The organization of GRAP is not an ideal-type; it is based on a strong commitment of people involved that implies numerous working hours and a flow of stressful situations. But, all the actors are conscious of this peculiar situation, that defines the mix between activism and entrepreneurship, and justify the continual flow of innovation practices related to work issues. GRAP can be thus described as a reflexive and innovative organization: the process in which these actors are involved accurately corresponds to the "multi-actor whirlwind", a term used by Akrich et al. (1988) in reference to innovation. This is clearly a collective process of conceptualization built up over time and made up of learning curves, ongoing back-andforth exchanges and negotiations whose importance cannot be determined in advance. It is a process that has not been completed, and the new rules, which this organization intends to produce, have not yet been formalized and are not taken for granted.

Finally, the paper brings a contribution to better understand how entrepreneurship and activism can be combined. Our analysis has been focused on operations of translation of frame into strategic action and organization forms. Based on a single case, the results cannot be generalized. However, the analysis enables to underline some assumptions that could be extended to others alternative food sectors in a comparative perspective. Also, it could be interesting to investigate others fields in order to identify new tactics and strategy of entrepreneurial actions that could generate a social change.

\section{References}

Akrich M., Callon M., Latour B., (1988), A quoi tient le succès des innovations? Premier épisode: L'art de l'intéressement, Annales des Mines : Gérer et comprendre, p. 4-17.

Brunori, G., Rossi, A. and Guidi, F. (2012), On the New Social Relations around and beyond Food. Analysing Consumers' Role and Action in Gruppi di Acquisto Solidale (Solidarity Purchasing Groups). Sociologia Ruralis, 52, DOI:10.1111/j.14679523.2011.00552.x

Dean, T. and McMullen, J. (2007) Toward a theory of sustainable entrepreneurship: reducing environmental degradation through entrepreneurial action, Journal of Business Venturing, Vol. 22, No. 1, pp.60-76. DOI:10.1016/j.jbusvent.2005.09.003

Debray C. (2012), Diriger un hypogroupe : évolution du management, et des modes de contrôle, Travail et emploi, $\mathrm{n}^{\circ} 130, \mathrm{p}$. 39-55. DOI : 10.4000/travailemploi.5691

Di Domenico, M., Haugh, H. and Tracey, P. (2010), Social bricolage: Theorizing social value creation in social enterprises. Entrepreneurship Theory and Practice, 34 (4), pp. 681-703. DOI: 10.1111/j.1540-6520.2010.00370.x

Dubuisson-Quellier S., Lamine C., Le Velly R. (2011), Citizenship and Consumption: Mobilisation in Alternative Food Systems in France, Sociologia Ruralis, Vol 51, n³. DOI: 10.1111/j.1467-9523.2011.00540.x

Fressoli M., Around E, Abrol D, Smith A, Ely A., Dias R. (2014), When grassroots innovation movements encounter mainstream institutions: implications for models of inclusive innovation, Innovation and Development, 4:2, 277-292. DOI: 10.1080/2157930X.2014.921354

Glew D.J, O’Leary-Kelly A. M, Griffin R. W., Van Fleet D.D. (1995), Participation in Organizations: A Preview of the Issues and Proposed Framework for Future Analysis, Journal of Management, Vol. 21, No. 3, 395421.

Hockerts, K. \& Wüstenhagen, R. (2010), Greening Goliaths versus emerging Davids. Theorizing about the role of incumbents and new entrants in sustainable entrepreneurship. Journal of Business Venturing, 25(5), 481-492. DOI: 10.1016/j.jbusvent.2009.07.005

Horwitch M., Mulloth B. (2010) The interlinking of entrepreneurs, grassroots movements, public policy and hubs of innovation: The rise of Cleantech in New York City, Journal of High Technology Management Research, 21 : 23-30. DOI: 10.1016/j.hitech.2010.02.004

Gibbs, D. (2009), Sustainability entrepreneurs, ecopreneurs and the development of a sustainable economy, Greener Management International, Vol. 55, pp.63-78.

Goodman D., Dupuis E.M., Goodman M. K. (2012), Alternative Food Networks. Knowledge, Practice and Politics, Routledge, London and New York

Greenwood, D. J., Whyte W.F., Harkavy I. (1993), Participatory action research as a process and as a goal. Human Relations, 46: 175-192. 
Laville JL. (2009), The Solidarity Economy: An International Movement, RCCS Annual Review, 2. DOI : $10.4000 /$ rccsar.202

Lawrence T. and Subbady R. (2006), Institutions and institutional work, Handbook of Organization Studies, Clegg S., Hardy C., Nord W et Lauwrence T., (Eds), Sage London, p. 215-254.

Le Velly R. \& Dufeu I. (2016), Alternative food networks as "market agencements": Exploring their multiple hybridities, Journal of Rural Studies, 43: 173-182. DOI : 10.1016/j.jrurstud.2015.11.015

Mair, J., \& Marti, I. (2006). Entrepreneurship in and around institutional voids: A case study from Bangladesh. Journal of World Business, 41, 36-44. DOI: 10.1016/j.jbusvent.2008.04.006

Marchesnay M. (1991), De l'hypofirme à l'hypogroupe : naissance, connaissance, reconnaissance, Cahiers du LERASS, ${ }^{\circ} 23$, pp. 33-49.

Nicholls A. (2010), Fair Trade: Towards an Economics of Virtue. Journal of Business Ethics. 92, p. 241-255. DOI: 10.1007/s10551-010-0581-3

Neumann, J.E. (1989). Why people don't participate in organizational change. Pp. 181-212 in R. Woodman \& W. Pasmore (Eds.), Research in organizational change and developrnenr, Vol. 3. Greenwich, CT: JAI Press.

Parrish, B.D. (2010), Sustainability-driven entrepreneurship: principles of organization design, Journal of Business Venturing, Vol. 25, No. 5, pp.510-523. DOI: 10.1016/j.jbusvent.2009.05.005

Pacheco, D.F., Dean, T.J. and Payne, D.S. (2010), Escaping the green prison: entrepreneurship and the creation of opportunities for sustainable development, Journal of Business Venturing, Vol. 25, n5, pp.464-480. DOI: 10.1016/j.jbusvent.2009.07.006

Pinkse J., Groot K. (2013), Sustainable Entrepreneurship and Corporate Political Activity: Overcoming Market Barriers in the Clean Energy Sector, Entrepreneurship Theory and Practice, p. 1042-2587. DOI: 10.1111/etap.12055

Renting H., Schermer M., Rossi A. (2012) Building Food Democracy: Exploring Civic Food Networks and Newly Emerging Forms of Food Citizenship, International Journal of Sociology of Agriculture \& Food, 19(3).

Rossi A. (2017), Beyond Food Provisioning: The Transformative Potential of Grassroots Innovation around Food, Agriculture 7, 6, p. 1-21. DOI:10.3390/agriculture7010006

Schaltegger, S. (2002), A framework for ecopreneurship. Leading bioneers and environmental managers to ecopreneurship', Greener Management International, Vol. 38, pp.45-59.

Smith A., Fressoli M., Thomas H. (2014), Grassroots innovation movements: challenges and contribution, Journal of Cleaner Production, vol. 63 n¹5, pp. 114-124. DOI: 10.1016/j.jclepro.2012.12.025

Smith A., Stirling A. et Berkhout F. (2005), The governance of sustainable socio-technical transitions, Research Policy, vol. 34, pp. 1491-1510. DOI: 10.1016/j.respol.2005.07.005

Smith, W.K., Gonin, M. and Besharov, M.L. (2013), Managing social-business tensions: a review and research agenda for social enterprise, Business Ethics Quarterly, Vol. 23, No. 3, pp.407-442. DOI:10.5840/beq201323327

Spear R. (2010), Social Entrepreneurship and Social Movements, Skoll Colloquium on Social Entrepreneurship, Oxford University, June.

Torres O. \& Julien PA (2005), Specificity and Denaturing of Small Business, International Small Business Journal, Vol. 23(4): 355-377. DOI: $10.1177 / 0266242605054049$

Van den Broek, T. A., Ehrenhard, M. L., Langley, D. J. and Groen, A. J. (2012), Dotcauses for sustainability: combining activism and entrepreneurship. Journal Public Affairs, vol. 12, pp. 214-223. DOI: 10.1002/pa.1435

Vasi, I.B. (2009), "New heroes, old theories? Toward a sociological perspective on social entrepreneurship", in Ziegler, R. (Ed.), An Introduction to Social Entrepreneurship: Voices, Preconditions, Contexts, Edward Elgar, Cheltenham, pp. 155-73

Watts, D., Ilbery, B., Maye, D. (2005) Making re-connections in agro-food geography: alternative systems of food provision, Progress in Human Geography, 29, pp. 22-40. DOI: 10.1191/0309132505ph526oa

Weinberg, A. (1998), Distinguishing among green businesses: growth, green and anomie, Society \& Natural Resources, Vol. 11, No. 3, pp.241-250. DOI: 10.1080/08941929809381076

Zahra SA, Gedajlovic E, Neubaum DO, Shulman JM. (2009). A typology of social entrepreneurs: Motives, search processes and ethical challenges. Journal of Business Venturing. 24(5) 519-532. DOI: 10.1016/j.jbusvent.2008.04.007 